Maciej Szczepkowski

\title{
ZNACZENIE PODATKÓW MAJĄTKOWYCH W DOCHODACH MIAST REGIONU NOWEJ ANGLII
}

\section{Wprowadzenie}

Zarówno system, jak i gospodarka finansowa samorządu lokalnego w znacznym stopniu podporządkowane są obranej koncepcji samorządu. Koncepcje te ulegały zmianie w różnych krajach na przestrzeni lat. Są one zależne przede wszystkim od funkcji, jakie spełnia państwo. Funkcje te kształtują stosunki między samorządem lokalnym a państwem ${ }^{1}$. W związku z różnicami występującymi w poszczególnych krajach także struktura dochodów poszczególnych jednostek samorządu terytorialnego nie jest jednorodna, a znaczenie fiskalne poszczególnych składowych dochodu może być inne.

Głównym źródłem dochodów władzy publicznej są podatki w różnej formie. Cel fiskalny był i jest po dzień dzisiejszy decydującym motywem pobierania podatków i w dużym stopniu determinuje ich konstrukcję ${ }^{2}$.

Celem niniejszego artykułu będzie określenie fiskalnej roli podatków majątkowych w dochodach jednostek samorządu terytorialnego w miastach regionu Nowa Anglia w USA.

W artykule na wstępie zaprezentowano strukturę samorządu terytorialnego w Stanach Zjednoczonych, przedstawiono poszczególne jednostki samorządu terytorialnego oraz ich liczebność w oparciu od dane statystyczne Bureau of the Census. Kolejna część artykułu poświęcona jest strukturze dochodów jednostek samorządu terytorialnego. Szczególna uwaga autora skoncentrowana jest na podatkach majątkowych w regionie Nowa Anglia, gdzie przeprowadzono badania statystyczne na przykładzie największych miast regionu w latach 2008-2011. W końcowej części artykułu autor odnosi się do teorii podatku jedynego, którą próbuje skonfrontować z wynikami przeprowadzonych analiz.

1 E. Denek, J. Sobiech, J. Wolniak, Finanse publiczne, Wydawnictwo Naukowe PWN, Warszawa 2001.

2 Ibidem. 


\section{Struktura samorządu lokalnego w Stanach Zjednoczonych}

Historia samorządu lokalnego w Stanach Zjednoczonych sięga początków czasów kolonialnych. W XVII w. kolonie miały silną autonomię, ale konieczność organizacji lokalnej społeczności w celach gospodarczych i obronnych wymusiła zapoczątkowanie wykształcania się jednostek samorządowych. Zwłaszcza wojna secesyjna w USA doprowadziła do znacznego rozwoju struktur lokalnych. W części stanów najważniejszą rolę pełniły hrabstwa, w innych największe znaczenie miały gminy ${ }^{3}$. W XIX w. na znaczeniu zaczęły zyskiwać gminy - istotnie rosła ich liczba na podstawie decyzji władz stanowych.

Amerykańska struktura samorządowa jest konstrukcją niezwykle rozbudowaną. Powodem takiego stanu rzeczy jest fakt, iż Stany Zjednoczone to federacja 50 stanów o bardzo zróżnicowanym i często autonomicznym prawodawstwie, ograniczonym jedynie przez ustawodawstwo federalne. Należy również zaznaczyć, że poszczególne struktury powstawały w różnym okresie, a lokalne społeczności musiały przystosowywać się do różnorodnych warunków otoczenia. W wielu stanach ze względu na nastroje społeczne istniała chęć do uniezależniania się od istniejących już struktur samorządowych i tworzenia nowych ${ }^{4}$.

Obecnie Bureau of the Census, jedna $\mathrm{z}$ agencji rządowych wchodzących w skład Departamentu Handlu Stanów Zjednoczonych, która jest odpowiedzialna za spis ludności Stanów Zjednoczonych, wyróżnia cztery podstawowe rodzaje jednostek samorządu terytorialnego. Dwa pierwsze uznawane są za uniwersalne, a pozostałe dwa za celowe:

- gminy (municipalities) - 36011 gmin, w których skład wchodzą gminy niezawierające okręgów miejskich (19492) oraz gminy miejskie (16 519); w wielu stanach gminy niezależnie od ich typu posiadają podobne uprawnienia i są zobligowane do spełniania określonych funkcji;

- hrabstwa (counties) - 3301 rządów hrabstw znajduje się w 48 stanach, wyjątek stanowią stany: Connecticut i Rhode Island oraz Dystrykt Columbia w stanie Waszyngton;

- okręgi (gminy) miejskie (town ships) - 16519 okręgów;

- okręgi specjalne (special districts) - 37381 okręgów, jednostki specjalnego przeznaczenia, które istnieją jako oddzielne podmioty o znacznej samodzielności

3 E.T. Howe, T.J. Reeb, The Historical Evolution of State and Local Tax Systems, 1997, http://citeseerx.ist. psu.edu/viewdoc/download?doi=10.1.1.197.3683\&rep=rep1\&type=pdf [dostęp 27.01.2015].

4 D.R. Berman, Local Government and the States: Autonomy, Politics and Policy, M.E. Shape, Inc., New York 2003. 
administracyjnej i fiskalnej od hrabstw, gmin i okręgów miejskich; mają one na celu świadczenie usług, które nie zostały zabezpieczone przez gminę, okręg miejski czy hrabstwo.

\section{Podatki majątkowe jako źródło dochodów amerykańskich miast}

Rola poszczególnych składników dochodów jednostek samorządu terytorialnego w Stanach Zjednoczonych ulegała zmianie na przestrzeni lat. W początkowym okresie funkcjonowania samorządu główne źródło dochodów stanowiły podatki majątkowe - 77,4\% dochodów5. W czasach Wielkiego Kryzysu, a więc pod koniec lat 20. XX w. nastąpił znaczący spadek ściągalności Property Tax. Było to spowodowane tworzonymi pod dużym naporem opinii publicznej zwolnieniami wielu rodzajów własności od podatku oraz znaczące obniżenie stawek. Działania te były później mocno krytykowane, ponieważ ulgi dotyczyły w dużej części ludzi zamożnych, a podatek dotykał najbardziej najuboższych. Działania te w znaczący sposób uderzyły w dochody jednostek samorządu terytorialnego, ponieważ głównym składnikiem Property Tax stał się podatek od nieruchomości mieszkalnych.

Po II wojnie światowej w wielu stanach wprowadzono dużą liczbę ulg i zwolnień, zwłaszcza dla ludzi najbiedniejszych, zmniejszono w znaczącym zakresie opodatkowanie gospodarstw rolnych oraz zwolniono $\mathrm{z}$ opodatkowania osoby starsze i niepelnosprawne ${ }^{6}$. Na przestrzeni lat 1942-2002 widoczny jest istotny spadek fiskalnego znaczenia podatków majątkowych, co ilustruje rysunek 1 .

Warto zatem przyjrzeć się bliżej składnikom dochodów poszczególnych gmin i przeanalizować fiskalne znaczenie poszczególnych składowych. Na samym początku trzeba zaznaczyć, iż znaczenie elementów dochodów w zależności od stanu jest bardzo zróżnicowane. Za istotne należy uznać badania przeprowadzone przez J. Edwina Bentona ${ }^{7}$, który przeanalizował źródła dochodów w hrabstwach, okręgach specjalnych, okręgach szkolnych i gminach w latach 1962-2002. Wyniki badań odnoszące się do okręgów miejskich w roku 2002 przedstawia tabela 1.

5 U.S. Census of Governments, Historical Statistics of State and Local Finance, 1902-1953, Washington 2003, http://www.census.gov [dostęp 21.01.2015].

6 R. Carlson, A Brief History of Property Tax, Fair \& Equitable, Kansas City 2004, Nr 2, s. 3-9, http:// www.iaao.org/uploads/a_brief_history_of_property_tax.pdf [dostęp 27.01.20 15].

7 J.E. Benton, Trends in Local Government Revenues: The Old, the New, and the Future, w: Municipal Revenues and Land Policies, red. G. Ingram, Y.-H. Hong, Lincoln Institute of Land Policy, Cambridge 2010. 
Rysunek 1. Źródła dochodów gmin w Stanach Zjednoczonych w latach 1942-2002

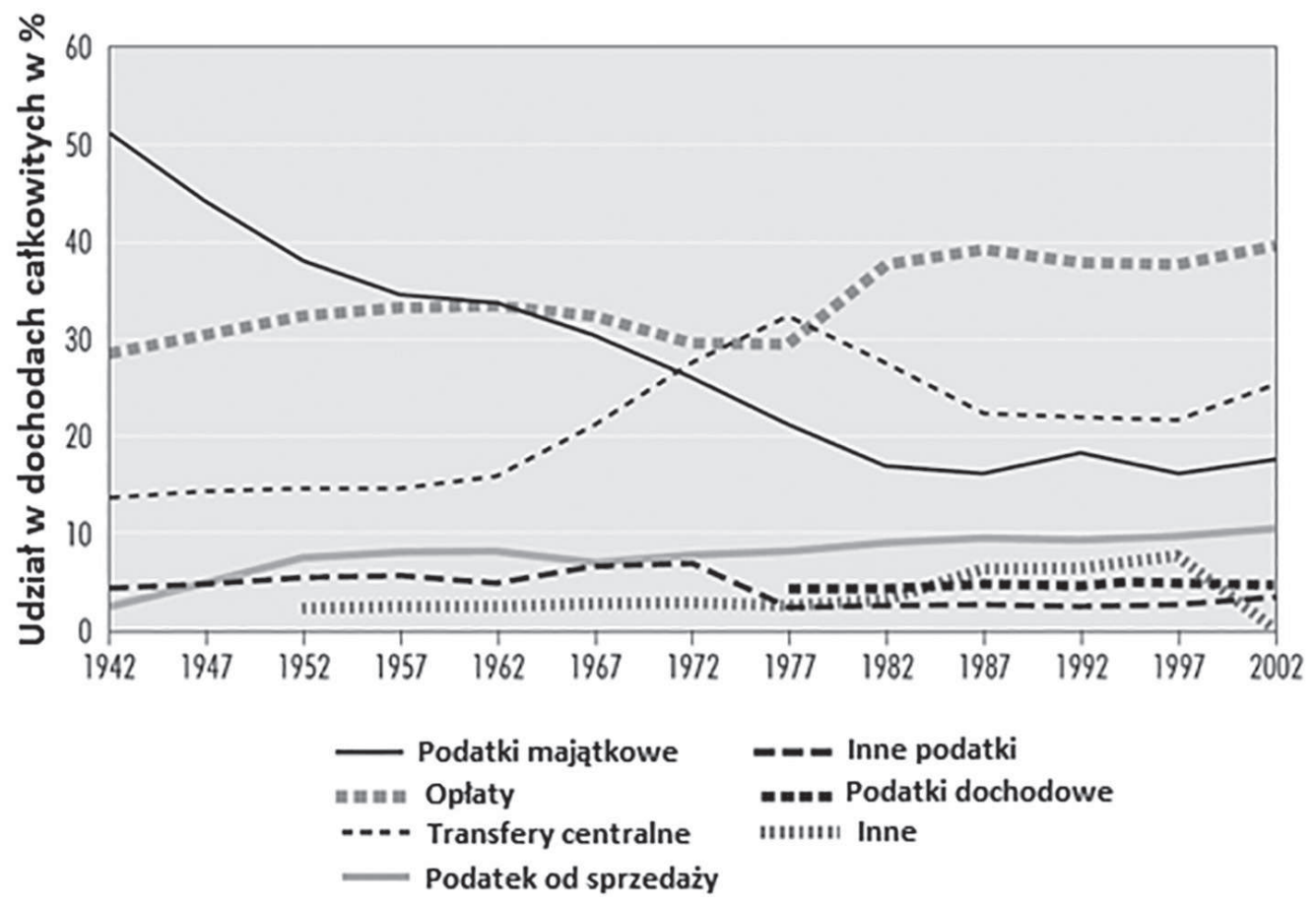

Źródło: Opracowanie własne na podstawie: M.A. Pagano, Creative Designs of the Patchwork Quilt of Municipal Finance, w: Municipal Revenues and Land Policies, red. G. Ingram, Y.-H. Hong, Lincoln Institute of Land Policy, Cambridge 2010.

Tabela 1. Struktura dochodów miast według regionów w 2002 r. (\% dochodów całkowitych)

\begin{tabular}{|c|c|c|c|c|c|}
\hline \multirow{3}{*}{ Region } & \multirow{3}{*}{$\begin{array}{l}\text { Transfery } \\
\text { centralne }\end{array}$} & \multicolumn{4}{|c|}{ Własne źródło dochodów } \\
\hline & & \multirow{2}{*}{ razem } & \multicolumn{2}{|c|}{ podatki lokalne } & \multirow{2}{*}{ opłaty } \\
\hline & & & podatki majątkowe & inne podatki & \\
\hline Nowa Anglia & 44 & 56 & 43 & 0 & 13 \\
\hline Stany środkowoatlantyckie & 42 & 58 & 20 & 22 & 16 \\
\hline Stany północne centrum & 28 & 72 & 20 & 19 & 33 \\
\hline Stany południowe & 23 & 77 & 21 & 21 & 35 \\
\hline Stany zachodnie & 21 & 79 & 16 & 27 & 36 \\
\hline
\end{tabular}

Źródło: Opracowanie własne na podstawie: J.E. Benton, Trends in Local Government Revenues: The Old, the New, and the Future, w: Municipal Revenues and Land Policies, red. G. Ingram, Y.-H. Hong, Lincoln Institute of Land Policy, Cambridge 2010.

Ponad 40\% dochodów całkowitych miast Nowej Anglii i stanów środkowoatlantyckich stanowiły transfery z funduszy centralnych (głównie stanowych). W innych regionach znaczenie tych funduszy było znacznie mniejsze i nie przekraczało $30 \%$. Miasta w stanach: południowych, zachodnich i północnego centrum bazują w dużo 
większym stopniu na własnych źródłach dochodu - głównie opłatach lokalnych (ponad 30\% dochodów całkowitych), które pozwalają na pokrycie wydatków lokalnych.

Mimo widocznego zjawiska spadku fiskalnego znaczenia podatków majątkowych w latach 1942-2002 (zob. rys. 1) w regionie Nowej Anglii podatki te stanowily 43\% ogółu dochodów miast. $\mathrm{W}$ pozostałych regionach podatki majątkowe stanowiły od 16\% do 21\% ogółu dochodów. Powodem uzależnienia miast Nowej Anglii od podatków majątkowych jest fakt, iż są to jedyne podatki, które trafiają do budżetu miast $\mathrm{w}$ tym regionie. Inaczej sytuacja wygląda w innych częściach USA, gdzie pozostałe podatki stanowią od 19\% do 27\% (stany zachodnie). Innym istotnym kryterium różnicującym strukturę dochodów miast jest ich wielkość. Strukturę dochodów miast według wielkości populacji w 2002 r. przedstawia tabela 2.

Tabela 2. Struktura dochodów miast według wielkości populacji w 2002 r. (\% dochodów całkowitych)

\begin{tabular}{|l|c|c|c|c|c|}
\hline \multirow{2}{*}{ Wielkość populacji } & \multirow{2}{*}{$\begin{array}{l}\text { Transfery } \\
\text { centralne }\end{array}$} & \multirow{2}{*}{ razem } & \multicolumn{3}{|c|}{ Wodasne źródło dochodów } \\
\cline { 3 - 5 } & & & podatki majątkowe & inne podatki & \multirow{2}{*}{ opłaty } \\
\hline 300000 i więcej & 34 & 66 & 16 & 25 & 25 \\
\hline 100 000-299 999 & 30 & 70 & 22 & 19 & 29 \\
\hline $25000-99999$ & 25 & 75 & 25 & 20 & 30 \\
\hline Poniżej 25 000 & 23 & 77 & 23 & 19 & 35 \\
\hline
\end{tabular}

Źródło: Jak do tab. 1.

Transferami funduszy centralnych w największym stopniu były wspierane budżety dużych miast (ponad 300 tys. mieszkańców). Im mniejsze miasto, tym mniejszy był procentowy udział tych transferów. Oznacza to, iż dochody tych miast musiały w znaczący sposób opierać się na dochodach własnych. W przypadku miast małych i średniej wielkości, których populacja nie przekraczała 100 tys. mieszkańców, największe znaczenie miały opłaty kształtujące się na poziomie 30-35\% dochodów całkowitych. Jeśli chodzi o podatki majątkowe, to ich udział był największy w przypadku miast małych (23-25\%), a mniejszy w miastach średnich i dużych (16-22\%). Inną zależność można zauważyć, jeśli chodzi o pozostałe podatki, których udział w dochodach był największy w dużych miastach i wynosił 25\%.

Autor w dalszej części opracowania postanowił bliżej przyjrzeć się regionowi Nowej Anglii, w którym głównym pochodzącym z podatków źródłem dochodów własnych miast był podatek majątkowy - Property Tax.

Przedmiotem badania były największe pod względem liczby ludności miasta każdego z sześciu stanów regionu Nowa Anglia - Boston (Massachusetts), Providence 
(Rhode Island), Bridgeport (Connecticut), Manchester (New Hampshire), Portland (Maine) oraz Burlington (Vermont).

Analiza struktury dochodów wybranych miast dotyczy lat 2008-2011, a więc okresu, w którym rozpoczął się kryzys finansowy. Kryzys finansowy spowodował znaczne pogorszenie sytuacji finansów lokalnych ${ }^{8}$. Według badań przeprowadzonych przez McNichola i Johnsona 47 stanów musiało kompensować swoje długi (w sumie około 158 mld USD) zanim przyjęto budżety na 2010 r. Spośród wszystkich stanów największą dziurę budżetową można było zaobserwować w stanie Kalifornia (45,5 mld USD), co stanowiło blisko 44\% wszystkich funduszy, jakimi dysponowały władze stanu. Jeszcze gorzej sytuacja wyglądała w 2009 r. w stanie Arizona, gdzie deficyt budżetowy przekroczył 50\% dochodów. Wiele innych stanów było zmuszonych w tym czasie do redukcji wydatków i odkładania na późniejszy termin projektów infrastrukturalnych ${ }^{9}$. Mimo nadziei, że sytuacja ulegnie znaczącej poprawie do końca roku 2009, w wielu pracach naukowych widoczny był pesymizm i przewidywania, iż zwłaszcza sytuacja finansów publicznych się nie zmieni ${ }^{10}$. Warto odnotować także fakt, że przeciętnie wydatki amerykańskich miast wzrosły w $2009 \mathrm{r}$. o $2,5 \%$, podczas gdy przeciętne dochody zmniejszyły się o $0,4 \%$. Jedną z przyczyn tego zjawiska były, jak zaznaczają Hoene i Pagano, zawirowania na amerykańskim rynku nieruchomości, a co za tym idzie zmniejszenie wpływów z tytułu podatku od nieruchomości, który jest jednym z głównych źródeł dochodów samorządów lokalnych w niektórych stanach.

Wątpliwe wydaje się zatem bezkrytyczne porównywanie uzyskanych rezultatów badań z danymi dotyczącymi roku 2002. Za istotną należy jednak uznać próbę wychwycenia widocznych tendencji, które zaszły w strukturze dochodów na przestrzeni lat 2002-2011. Strukturę dochodów miasta Boston w latach 2008-2011 przedstawia tabela 3 .

\footnotetext{
8 Municipal Revenues and Land Policies, red. G. Ingram, Y.-H. Hong, Lincoln Institute of Land Policy, Cambridge 2010.

9 E. McNichol, N. Johnson, Recession continues to batter state budgets; State responses could slow recovery, „Center on Budget and Policy Priorities” 2009.

10 Ch. Hoene, M.A. Pagano, City fiscal conditions in 2009, „Research Brief on America's Cities” Nr 2, 2009, s. 1-16; M. Muro, Ch. Hoene, Fiscal challenges facing cities: Implications for recovery, „The Blueprint for American Prosperity" Nr 11, 2009, s. 1-16.
} 
Tabela 3. Struktura dochodów miasta Boston w latach 2008-2011 (w \%)

\begin{tabular}{|l|c|c|c|c|c|}
\hline \multirow{2}{*}{ Rok } & \multirow{2}{*}{\begin{tabular}{l} 
Transfery \\
\cline { 3 - 5 }
\end{tabular}} & centralne & \multirow{2}{*}{ razem } & \multicolumn{4}{|c|}{ Własne źródło dochodów } \\
\cline { 4 - 5 } & & & podatki majątkowe & inne podatki & \multirow{2}{*}{ opłaty } \\
\hline 2008 & 21 & 79 & 56 & 0 & 23 \\
\hline 2009 & 19 & 81 & 58 & 0 & 23 \\
\hline 2010 & 18 & 82 & 60 & 0 & 22 \\
\hline 2011 & 17 & 83 & 65 & 0 & 18 \\
\hline
\end{tabular}

Źródło: Opracowanie własne na podstawie danych z Departamentu Finansów miasta Boston.

Strukturę dochodów miasta Providence w latach 2008-2011 przedstawia tabela 4.

Tabela 4. Struktura dochodów miasta Providence w latach 2008-2011 (w \%)

\begin{tabular}{|l|c|c|c|c|c|}
\hline \multirow{2}{*}{ Rok } & \multirow{2}{*}{\begin{tabular}{l} 
Transfery \\
\cline { 4 - 5 }
\end{tabular}} & centralne & \multirow{2}{*}{ razem } & \multicolumn{4}{|c|}{ Własne źródło dochodów } \\
\cline { 3 - 5 } & & & podatki majątkowe & inne podatki & \multirow{2}{*}{ opłaty } \\
\hline 2008 & 43 & 57 & 38 & 0 & 19 \\
\hline 2009 & 40 & 60 & 39 & 0 & 21 \\
\hline 2010 & 41 & 59 & 43 & 0 & 16 \\
\hline 2011 & 36 & 64 & 39 & 0 & 25 \\
\hline
\end{tabular}

Źródło: Opracowanie własne na podstawie danych z Departamentu Finansów miasta Providence.

Strukturę dochodów miasta Bridgeport w latach 2008-2011 przedstawia tabela 5.

Tabela 5. Struktura dochodów miasta Bridgeport w latach 2008-2011 (w \%)

\begin{tabular}{|c|c|c|c|c|c|}
\hline \multirow{3}{*}{ Rok } & \multirow{3}{*}{$\begin{array}{l}\text { Transfery } \\
\text { centralne }\end{array}$} & \multicolumn{4}{|c|}{ Własne źródło dochodów } \\
\hline & & \multirow{2}{*}{ razem } & \multicolumn{2}{|c|}{ podatki lokalne } & \multirow{2}{*}{ opłaty } \\
\hline & & & podatki majątkowe & inne podatki & \\
\hline 2008 & 60 & 40 & 37 & 0 & 3 \\
\hline 2009 & 58 & 42 & 39 & 0 & 3 \\
\hline 2010 & 55 & 45 & 42 & 0 & 3 \\
\hline 2011 & 53 & 47 & 43 & 0 & 4 \\
\hline
\end{tabular}

Źródło: Opracowanie własne na podstawie danych z Departamentu Finansów miasta Bridgeport.

Strukturę dochodów miasta Manchester w latach 2008-2011 przedstawia tabela 6. 
Tabela 6. Struktura dochodów miasta Manchester w latach 2008-2011 (w \%)

\begin{tabular}{|l|c|c|c|c|c|}
\hline \multirow{2}{*}{ Rok } & \multirow{2}{*}{$\begin{array}{l}\text { Transfery } \\
\text { centralne }\end{array}$} & \multirow{2}{*}{ razem } & \multicolumn{4}{|c|}{ Własne źródło dochodów } \\
\cline { 4 - 5 } & & & podatki majątkowe & inne podatki & \multirow{2}{*}{ opłaty } \\
\cline { 4 - 6 } & 23 & 77 & 34 & 0 & 43 \\
\hline 2008 & 18 & 82 & 38 & 0 & 44 \\
\hline 2010 & 16 & 84 & 41 & 0 & 43 \\
\hline 2011 & 16 & 84 & 39 & 0 & 45 \\
\hline
\end{tabular}

Źródło: Opracowanie własne na podstawie danych z Departamentu Finansów miasta Manchester.

Strukturę dochodów miasta Portland w latach 2008-2011 przedstawia tabela 7.

Tabela 7. Struktura dochodów miasta Portland w latach 2008-2011 (w \%)

\begin{tabular}{|l|c|c|c|c|c|}
\hline \multirow{2}{*}{ Rok } & \multirow{2}{*}{$\begin{array}{l}\text { Transfery } \\
\text { centralne }\end{array}$} & \multirow{2}{*}{ razem } & \multicolumn{4}{|c|}{ Własne źródło dochodów } \\
\cline { 4 - 6 } & & & podatki majątkowe & inne podatki & \multirow{2}{*}{ opłaty } \\
\hline 2008 & 25 & 75 & 53 & 0 & 22 \\
\hline 2009 & 23 & 77 & 55 & 0 & 22 \\
\hline 2010 & 23 & 77 & 54 & 0 & 23 \\
\hline 2011 & 26 & 74 & 54 & 0 & 20 \\
\hline
\end{tabular}

Źródło: Opracowanie własne na podstawie danych z Departamentu Finansów miasta Portland.

Strukturę dochodów miasta Burlington w latach 2008-2011 przedstawia tabela 8.

Tabela 8. Struktura dochodów miasta Burlington w latach 2008-2011 (w \%)

\begin{tabular}{|l|c|c|c|c|c|}
\hline \multirow{2}{*}{ Rok } & \multirow{2}{*}{\begin{tabular}{l} 
Transfery \\
\cline { 3 - 5 }
\end{tabular}} & centralne & \multirow{2}{*}{ razem } & \multicolumn{4}{|c|}{ Własne źródło dochodów } \\
\cline { 3 - 5 } & & & podatki majątkowe & inne podatki & \multirow{2}{*}{ opłaty } \\
\hline 2008 & 58 & 42 & 23 & 3 & 16 \\
\hline 2009 & 58 & 42 & 22 & 4 & 16 \\
\hline 2010 & 57 & 43 & 22 & 3 & 17 \\
\hline 2011 & 55 & 45 & 24 & 4 & 18 \\
\hline
\end{tabular}

Źródło: Opracowanie własne na podstawie danych z Departamentu Finansów miasta Burlington.

Na podstawie przeprowadzonej analizy można stwierdzić, iż głównym źródłem dochodów miast Bridgeport, Burlington i Providence były transfery pochodzące z dotacji centralnych. Najwyższy poziom transfery te osiągnęły w 2008 r. - 43\% w przypadku Providence, 58\% w Burlington i 60\% w Bridgeport. W innych największych 
miastach regionu udział transferów centralnych był znacznie mniejszy i wynosił 21-25\%. W miastach regionu Nowa Anglia istotne składniki dochodów stanowiły także opłaty - średnio 15-20\% dochodów. Wyjątek stanowi Manchester - 45\% (w 2011 r.) oraz Bridgeport - 3\%. W przypadku wszystkich miast regionu najważniejszym i podatkowym źródłem dochodów były wpływy z podatków majątkowych - najwięcej, bo ponad 50\% udział w dochodach mają w przypadku miast Portland i Boston; najmniejszy stanowiły w Burlington i tylko w tym mieście nie są głównym podatkowym źródłem dochodów. Porównując rezultaty analizy w latach 2008-2011 z danymi z 2002 r., wyraźnie widać, że podatki majątkowe są w dalszym ciągu najistotniejszymi podatkami lokalnymi zasilającymi budżet miejski. W tym kontekście warto zastanowić się, czy tego rodzaju podatek można utożsamiać z popularną koncepcją tzw. podatku jedynego? Rozważania na ten temat będą przedstawione w dalszej części artykułu.

Analizując wysokość opłat i dotacji centralnych, nie można jednoznacznie stwierdzić, czy poziom tych dochodów uległ zmianie na przestrzeni lat, ponieważ ich znaczenie w poszczególnych miastach jest bardzo zróżnicowane.

\section{Koncepcja podatku jedynego a Property Tax w miastach Nowej Anglii}

Od lat można zaobserwować w wielu krajach próby oparcia polityki podatkowej na ogólnych jednolitych zasadach. Na system podatkowy składa się większa bądź mniejsza ilość podatków, które funkcjonują obok siebie. Zazwyczaj występuje wiele sprzeczności w ich wspólnym występowaniu. Jak stwierdza M. Kalinowski, „im więcej podatków występujących w danym systemie, tym więcej problemów pojawia się $\mathrm{w}$ związku z ich funkcjonowaniem w praktyce" ${ }^{11}$. Prowadzi to do przywoływania koncepcji tzw. podatku jedynego. Koncepcja ta zakłada zastąpienie wszystkich podatków - jednym podatkiem, który będzie w stanie efektywnie spełniać wszystkie funkcje podatków.

Teoria podatku jedynego została sformułowana przez fizjokratów z Francois Quesnayem na czele. Proponowali oni, aby dotychczasowe podatki zastąpić jednym podatkiem „od dochodów z renty gruntowej”. Propozycja ta jest konsekwencją podglądu fizjokratów, iż opodatkować powinno się tylko dochód czysty z ziemi, a podatki

11 M. Kalinowski, Rodzaje podatków i ich klasyfikacja oraz systemy podatkowe, w: System prawa finansowego, t. III: Prawo daninowe, red. L. Etel, Wolters Kluwer, Warszawa 2010. 
powinni płacić tylko ci, u których ten dochód czysty może powstawać, a więc właściciele ziemi ${ }^{12}$. Jak zauważa R. Rybarski, za pioniera i zwolennika podatku jedynego niesłusznie uważa się Sebastiana Vaubana (jeden z prekursorów fizjokratyzmu), który w swoim dziele Zarys dziesięciny królewskiej proponował, aby „Dziesięcina królewska obejmowała szereg podatków bezpośrednich, podatek od ziemi, budynków, płac, zarobków itp. Zniesione miały być tylko niektóre podatki, które zdaniem Vaubana były najbardziej dokuczliwe"13.

Przedstawiciel ekonomii klasycznej David Ricardo także utrzymywał, że ziemia jako ważny czynnik produkcji powinna zostać opodatkowana. Według niego wzrost populacji spowodował znaczący wzrost popytu na towary rolne. Rodziło to więc konieczność zwiększenia efektywności upraw wśród posiadaczy niedużej ilości gruntów słabszej jakości i generowało związane z tym dodatkowe koszty. Ricardo uzasadniał, że zwyżka kosztów może powodować wzrost cen artykułów rolnych. Wzrost cen powodował zatem wzrost zysków ze sprzedaży wśród posiadaczy gruntów o dużej efektywności upraw bez potrzeby ponoszenia dodatkowych kosztów. Według Ricarda wszystkie osiągnięte w ten sposób nadwyżki powinny być opodatkowane, gdyż nie stanowią rzeczywistych kosztów produkcji ${ }^{14}$.

Poglądy fizjokratów i Ricarda posłużyły jako podstawa dla amerykańskiej koncepcji podatku jedynego. Ruch ten nosił nazwę The Single Tax Movement i zyskał silne poparcie w Stanach Zjednoczonych pod koniec XIX w. Twórcą ruchu był Henry George, autor projektu systemu gospodarczego, który miał zachować „dynamikę kapitalizmu i rozpowszechniać swoje owoce bardziej sprawiedliwie"15.

George zaczął od założenia, że ziemia wraz z innymi zasobami naturalnymi jest wspólnym dziedzictwem wszystkich. Uważał on, że żadne osoby prywatne ani przedsiębiorstwa nie powinny być właścicielami gruntów, ale powinny mieć możliwość ich dzierżawienia. Adresatem czynszu powinna być władza publiczna, jako prawowity właściciel wszystkich gruntów. George sprzeciwiał się jakiemukolwiek opodatkowaniu aktywności produkcyjnej, co miało prowadzić do zwiększenia inwestycji w rolnictwo i przemysł. Postulaty Henry'ego George'a znalazły odzwierciedlenie w jego koncepcji podatku jedynego. Uważał on, że jedynym podatkiem powinien być podatek od nieruchomości, a jego wysokość powinna być ustalona w taki sposób, aby możliwe było osiągnięcie podstawowych celów władzy publicznej. Kwota płaconego podatku

${ }^{12}$ H. Fujak, Moralność a gospodarka - Antoni Popławski, w: Fizjokratyzm wczoraj i dziś: ekonomia, filozofia, polityka, red. J. Rosicka, Wydawnictwo AE w Krakowie, Kraków 1996.

13 R. Rybarski, Nauka Skarbowości, F. Wyszyński i S-ka, Warszawa 1935.

14 D. Cameron, Property Taxes, 1999, s. 1-11, http://encyclo.findlaw.com/6030book.pdf [dostęp 27.05.2014].

15 H. George, Progress and Poverty, Doubleday, Page \& Co., Garden City, NY 1920. 
stanowiłaby „czynsz” tych, którzy korzystają z ziemi. Podatki od dochodów z pracy i dochodów kapitałowych zostałyby za to całkowicie wyeliminowane ${ }^{16}$.

Oprócz koncepcji podatku jedynego jako podatku majątkowego pojawiło się także kilka innych koncepcji, w których podatek jedyny miał być: podatkiem od surowców, podatkiem od energii, podatkiem od dochodów czy podatkiem obrotowym $^{17}$. Te koncepcje nie są jednak przedmiotem niniejszego artykułu. Warto podkreślić, iż żadna z wymienionych idei nie została urzeczywistniona w taki sposób, aby faktycznie obowiązywał tylko i wyłącznie jeden podatek, dlatego też koncepcje te określa się wspólnym mianem „utopii podatkowych”18.

Nie inaczej zdaje się być w odniesieniu do Property Tax w miastach Nowej Anglii. Co prawda jest to jedyny podatek będący bezpośrednim podatkowym źródłem dochodów miast, należy jednak zauważyć, że dochody miast w znacznym stopniu bazują na transferach centralnych, a te opierają się na podatkach o zasięgu centralnym: głównie podatku dochodowym (Income Tax). Nie można zatem powiedzieć, że dochody budżetu lokalnego opierają się tylko i wyłącznie na podatkach majątkowych.

\section{Zakończenie}

Przeprowadzone badania dotyczące fiskalnego znaczenia podatków majątkowych w dochodach amerykańskich miast pozwalają na sformułowanie następujących wniosków:

- Udział podatków majątkowych w dochodach miast od wielu lat jest zróżnicowany - największą rolę podatki majątkowe spełniają w przypadku miast regionu Nowa Anglia, najmniejsze w przypadku stanów na zachodnim wybrzeżu.

- W czasie kryzysu finansowego znacząco wzrosła rola transferów centralnych, ale waga podatków majątkowych w dochodach miast Nowej Anglii nie zmniejszyła się w znaczący sposób.

- Podatki majątkowe są w większości przypadków głównym podatkowym źródłem dochodów własnych miast w regionie Nowej Anglii.

\footnotetext{
16 A.N. Young, The Single Tax Movement in the United States, Princeton University Press, New Jersey 1916.

17 Więcej na temat innych koncepcji podatku jedynego patrz: M. Kalinowski, op.cit., s. 73-74; C. Kosikowski, Finanse publiczne i prawo finansowe. Zagadnienia egzaminacyjne i seminaryjne, Wolters Kluwer, Warszawa 2013, s. 191-192.

18 A. Krajewska, Podatki - Unia Europejska, Polska, kraje nadbałtyckie, PWE, Warszawa 2004; C. Kosikowski, op.cit.
} 
- Nie można powiedzieć, że podatek Property Tax spełnia wszystkie funkcje zgodne z koncepcją podatku jedynego. Koncepcja ta pozostaje zatem „utopią podatkową”.

\section{Literatura}

Benton J.E., Trends in Local Government Revenues: The Old, the New, and the Future, w: Municipal Revenues and Land Policies, red. G. Ingram, Y.-H. Hong, Lincoln Institute of Land Policy, Cambridge 2010.

Berman D.R., Local Government and the States: Autonomy, Politics and Policy, M.E. Shape, Inc., New York 2003.

Cameron D., Property Taxes, 1999, s. 1-11, http://encyclo.findlaw.com/6030book.pdf

Carlson R., A Brief History of Property Tax, Fair \& Equitable, Kansas City 2004, Nr 2, s. 3-9, http://www.iaao.org/uploads/a_brief_history_of_property_tax.pdf

Denek E., Sobiech J., Wolniak J., Finanse publiczne, Wydawnictwo Naukowe PWN, Warszawa 2001.

Fujak H., Moralność a gospodarka - Antoni Popławski, w: Fizjokratyzm wczoraj i dziś: ekonomia, filozofia, polityka, red. J. Rosicka, Wydawnictwo AE w Krakowie, Kraków 1996.

George H., Progress and Poverty, Doubleday, Page \&Co., Garden City, NY 1920, http:// www.econlib.org/library/YPDBooks/George/grgPP.html

HFD, Comprehensive Annual Financial Report, 2011, http://www.hartford.gov/annual-report

Hoene Ch., Pagano M.A., City fiscal conditions in 2009, „Research Brief on America's Cities" Nr 2, 2009, s. 1-16.

Howe E.T., Reeb T.J., The Historical Evolution of State and Local Tax Systems, 1997, http:// citeseerx.ist.psu.edu/viewdoc/download?doi=10.1.1.197.3683\&rep=rep1\&type=pdf

Kalinowski M., Rodzaje podatków i ich klasyfikacja oraz systemy podatkowe, w: System prawa finansowego, t. III: Prawo daninowe, red. L. Etel, Wolters Kluwer, Warszawa 2010.

Kosikowski C., Finanse publiczne i prawo finansowe. Zagadnienia egzaminacyjne i seminaryjne, Wolters Kluwer, Warszawa 2013.

Krajewska A., Podatki - Unia Europejska, Polska, kraje nadbaltyckie, PWE, Warszawa 2004.

McNichol E., Johnson N., Recession continues to batter state budgets; State responses could slow recovery, „Center on Budget and Policy Priorities” 2009.

Municipal Revenues and Land Policies, red. G. Ingram, Y.-H. Hong, Lincoln Institute of Land Policy, Cambridge 2010.

Muro M., Hoene Ch., Fiscal challenges facing cities: Implications for recovery, „The Blueprint for American Prosperity" Nr 11, 2009, s.1-16. 
National League of Cities, Local Government Authority, Washington 2013, http://www. nlc.org/build-skills-and-networks/resources/cities-101/city-powers/local-government-authority.html

Pagano M.A., Creative Designs of the Patchwork Quilt of Municipal Finance, w: Municipal Revenues and Land Policies, red. G. Ingram, Y.-H. Hong, Lincoln Institute of Land Policy, Cambridge 2010.

Rybarski R., Nauka Skarbowości, F. Wyszyński i S-ka, Warszawa 1935.

U.S. Census of Governments, Historical Statistics of State and Local Finance, 1902-1953, Washington 2003, http://www.census.gov

Young A.N., The Single Tax Movement in the United States, Princeton University Press, New Jersey 1916.

\section{Role of property taxes in revenues of New England's cities}

The aim of this article is to delineate the role of property taxes in local government revenues in New England in the USA. In the paper I analyse the data from: Boston, Providence, Bridgeport, Manchester, Portland and Burlington. The article consists of three parts. The first part of the study describes local government in the US. The second part of the article shows structure of local government revenues. Finally, in connection with observed relations in revenues structure in New England's cities, the author discusses popular single tax theory.

Keywords: property taxes, city revenues, fiscal function, local finances, local government, single tax

\section{Rôle des impôts fonciers dans les recettes des villes de la Nouvelle-Angleterre}

L'objectif de cet article est de définir le rôle des impôts fonciers dans les recettes des gouvernements locaux en Nouvelle-Angleterre aux États-Unis. Dans l'article, nous analysons les données provenant de Boston, Providence, Bridgeport, Manchester, Portland et Burlington. Larticle se compose de trois parties. La première partie de l'étude décrit en général le gouvernement local aux États-Unis. La deuxième partie de l'article présente la structure des recettes des gouvernements locaux. 
Enfin, dans le cadre des relations observées dans la structure des recettes des villes de la Nouvelle-Angleterre, l'auteur traite de la théorie de la taxe unique populaire.

Mots-clés: impôts fonciers, recettes de la ville, fonction fiscale, finances locales, gouvernement local, taxe unique

\section{Фискальное значение налогов на имущество в доходах городов Новой Англии}

Целью статьи является определение фискального значения налогов на имущество в доходах местного самоуправления США, в частности городов в регионе Новой Англии. Исследование проводилось при использовании финансовых данных городов: Бостон, Провиденс, Бриджпорт, Манчестер, Портленд и Берлингтон. В первой части статьи представлена структура местных органов власти в США. Во второй - структура доходов единиц местного самоуправления. В заключении, учитывая наблюдаемые в ходе исследования зависимости в структуре доходов городов, автор относится к популярной концепции единого налога в контексте налогов на имущество.

Ключевые слова: налог на имущество, доходы города, фискальная функция налогов, местные финансы, местное самоуправление, единый налог 